\title{
Monetary policies and bank lending in developing countries: evidence from Sub-Sahara Africa
}

\author{
Kennedy Prince Modugu and Juan Dempere \\ Department of Accounting, Higher Colleges of Technology, \\ Abu Dhabi, United Arab Emirates
}

\begin{abstract}
Purpose - The purpose of this paper is to examine monetary policies and bank lending in the emerging economies of Sub-Sahara Africa.

Design/methodology/approach - The dynamic system-generalized method of moments (GMM) that overcomes issues of unobserved period and country-specific effects, as well as potential endogeneity of explanatory variables, is applied in the estimation exercise. The study uses the data for 80 banks across 20 SubSaharan African countries from 2010 to 2019.

Findings - The findings show that expansionary monetary policy such as an increase in money supply stimulates bank lending, while contractionary monetary policies like increase in the monetary policy rates by the central banks lead to credit contraction, albeit a weak effect due to possible underdevelopment of financial markets, institutional constraints, bank concentration and other rigidities in the system characteristic of developing countries that undermine the effectiveness of monetary policy transmission. Capital adequacy ratio and size of economic activities are other variables that significantly influence bank lending channels.

Practical Implication - Sub-Sahara Africa countries can enhance the effectiveness of monetary policy transmission on bank lending through the effective use of the transmission mechanism of changes in money supply and monetary policy rate.

Originality/value - While greater empirical attention has been devoted to the nexus between monetary policies and macroeconomic variables in country-specific studies, the connection between monetary policies and bank lending at an extensive regional or cross-country level is still scanty. For Sub-Saharan Africa, there is a palpable lack of empirical evidence on this. This study, therefore, seeks to fill this gap in a region where the impact of monetary policies on credit intermediation is crucial to the economic diversification efforts of the governments of Sub-Sahara Africa.
\end{abstract}

Keywords Monetary policy, Transmission mechanism, Bank lending channel, Financial intermediation, Developing countries

Paper type Research paper

\section{Introduction}

One of the banes to Africa's economic development is the paucity of funds required to grow the real sector of the economy. In particular, Sub-Sahara Africa is reputed for weak financial system stability, monetary policy somersault and the misalignment between fiscal and monetary policies. A combination of these factors has created a huge gap between the supply of and demand for capital. Monetary policy is a potent macroeconomic instrument for the achievement of price stability, full employment and economic growth. These objectives are subsumed in the context of economic stability and growth-based objectives of countries. As a core objective, the role of monetary policy is to achieve price stability through inflation

\section{JEL Classification - E44, E51, E52, E58, G21}

(C) Kennedy Prince Modugu and Juan Dempere. Published in Journal of Economics and Development. Published by Emerald Publishing Limited. This article is published under the Creative Commons Attribution (CC BY 4.0) licence. Anyone may reproduce, distribute, translate and create derivative works of this article (for both commercial and non-commercial purposes), subject to full attribution to the original publication and authors. The full terms of this licence may be seen at http://creativecommons. org/licences/by/4.0/legalcode.
Monetary policies and bank lending
Received 6 September 2021 Revised 14 November 2021 Accepted 4 January 2022

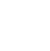


JED

24,3

218

control anchored on low and stable inflation that is consistent with output growth (Owoye and Onafowora, 2007). In achieving real sector growth through productivity, monetary policies through their pass-through channels influence credit intermediation using intermediate variables such as interest rate and money supply. Financial intermediation anchored on raising real sector growth can, therefore, be significantly influenced based on whether a monetary policy is expansionary or contractionary.

Among the monetary policy variables that impact the bank lending channels, the interest rate channel has a greater influence on the economy through its impact on lending and thus, the cost of loanable funds. An increase in the interest rate, for instance, affects the lending rate and thus the prices of goods and services and contributes directly to the domestic inflation rate. To stimulate the productive sectors and stem inflationary pressures, the monetary authorities fix the policy rates. Through the lending channels, the productive sectors of an economy are encouraged to contribute to rapid economic growth. A rise in the monetary policy rate, for instance, leads to credit contraction (credit squeeze), while a liberal monetary policy does the opposite to the real sector. Thus, a change in monetary policy influences the loanable fund rate and lending behavior of banks (Ozekhome, 2018).

For developing countries, particularly, the Sub-Saharan African region, the monetary policy credit channel is incredibly different and constrained. This is mainly due to underdeveloped financial systems, financial frictions and systemic structural rigidities. In developed economies, the existence of developed financial infrastructure aids the effectiveness of monetary policy transmission mechanisms to bank lending. In developing countries, institutional constraints obstruct financial intermediation and public policy effectiveness (Beck et al., 2000; Levine et al., 2000; Balogun, 2009). A weak legal environment, in addition to concentrated financial systems, also weakens monetary policy transmission (Mishra et al., 2012; Abuka et al., 2019).

Banks play a critical role in the monetary policy transmission mechanism principally through the lending channel to the real sector of the economy. The question, however, is whether monetary policy actions are effective in the credit intermediation process. The consensus among economists and policymakers is that monetary policy works or transmits principally through interest rates. For instance, a tightened policy by the central bank via an increase in reserve provision raises the interest rates. The rise in interest rates results in a reduction in spending by interest-sensitive sectors of the economy, like housing and purchases of durable goods by consumers. The interest rate mechanism constitutes an important mechanism through which banks play their part, given that a contraction in the supply of money, consisting of bank deposit liabilities, represents a key factor that leads to a rise in interest rates (Adimu, 2006).

Bernanke and Blinder (1989) suggest that the interest rate mechanism does not depend on the type of assets held by banks, as a similar reaction would take place irrespective of the sizes of assets that are held as loans or securities by banks. Consequently, monetary policies directly constrain the ability of bank lending. Through the credit channel, a restrictive monetary policy works not only by inducing interest rates to rise but also by directly restricting bank credit. Two critical issues have been the focus of recent literature on bank credit channels. The first is whether different categories of borrowers exist that are dependent on bank lending such that a little change in the willingness of banks to lend instantaneously affects their investment and spending decisions. The second is whether changes in monetary policies have a direct effect on bank lending. The two conditions are key for bank lending to play its role in the monetary transmission channel. Thus far, empirical investigation on the bank credit channel has yielded mixed and inconclusive evidence. Studies have shown that that disruption in bank credit due to asymmetric and unanticipated changes in monetary policies could affect economic activity. The current study probes into the latter, to provide new insights and perspectives on the monetary policy transmission-bank lending channel. 
While greater empirical attention has been devoted to the nexus between monetary policies and macroeconomic variables (e.g. monetary policy and investment, monetary policy and trade, monetary policy and growth, monetary policy and balance of payments) in country-specific studies, the connection between monetary policy and lending at an extensive regional or cross-country level is still scanty. For Sub-Saharan Africa, there is a palpable lack of empirical evidence on this. This study, therefore, seeks to fill this gap by empirically examining the monetary policy-bank lending nexus, drawing evidence from the Sub-Saharan African countries, where the impact of monetary policies on credit intermediation is crucial to effective policy management, given the quest to diversify the economic base and support growth through a private enterprise-led growth initiative. Accordingly, the study is relevant from the perspective of adducing empirical evidence that could inform policies to enhance monetary policy effectiveness for growth.

Following this introductory section, the rest of the paper is as follows: Section 2 provides the review of the literature, consisting of the theoretical, empirical and policy issues associated with monetary policies and lending in Africa. Section 3 contains the methodology, model specification and discussions on the data. The empirical results and analyses are presented in Section 4, and the evidence-based policy implications are contained in Section 5. Section 6 concludes the paper with some recommendations.

\section{Review of literature}

Monetary policy refers to a combination of measures designed to regulate the volume, value and cost of money in an economy, compatible with the expected level of economic activities to attain rapid economic, full employment, price stability and balance of payment equilibrium (Onyiewu, 2011). Iyoha (2004) defines monetary policy as "the attempt to achieve the national goals of full employment, without inflation, rapid economic growth and balance of payments equilibrium through the control of money supply, cost of credit and size of credit." Since the interest rate is the cost of credit, the monetary policy includes the control of money supply (trough the regulation of high-powered reserves) and the rate of interest. From a wider perspective, monetary policy may likewise be taken to include attempts to influence the external value of a domestic currency via exchange rate management.

\subsection{Theoretical literature}

2.1.1 Monetary policy transmission mechanism. Monetary policy has its roots in the works of Irving Fisher, who laid the basis for the quantity theory of money via the equation exchange. Both the monetarists and Keynesians explained several transmission mechanisms through which monetary policy affects bank lending. The monetarists suggest that a change in the money supply leads directly to a change in the real magnitude of money. Friedman (1968) effectively explained the role of monetary policy in influencing the cost and volume of credit. He argued that in the short run, an increase in money supply leads to a decrease in the interest rate, with a resultant increase in bank lending/credit. Thus, the interest rate, which is the cost of credit, is the main channel through which lending is influenced. In line with the monetarists' contention, Friedman and Schwartz (1963) state that an expansionary monetary policy via open market operations, raises the stock of money in commercial bank reserves and consequently, increases the ability of banks to create credit via the multiplier effect. Accordingly, a restrictive monetary policy affects the liquidity and the ability of banks to lend, thereby restricting loans to prime borrowers and business firms, leading to effective demand and investment contraction. The effectiveness of monetary policy transmission on lending, thus, depends on whether it is an expansionary or contractionary monetary policy. For an expansionary monetary policy reflected in the growing money supply, credit is increased, while a restrictive monetary policy inhibits banks' lending ability. In other words,
Monetary policies and bank lending 
JED

24,3

an increase in money supply or a lowering of the monetary policy rate, representing an easing in monetary policy engender a regime of increase in bank deposits and the volume of money that banks have to lend, while the reverse holds for a restrictive monetary policy (Ozekhome, 2018).

Keynesians, on the contrary, assert that a change in the money supply impacts activities in the financial markets, interest rate, credit, investment, output and prices. Modigliani (1963) supports this view, arguing monetary policy transmission mechanism affects banks' willingness to lend. When there is scarcity of funds at the banks due to a credit squeeze precipitated by contractionary monetary policy, credit rationing would occur (Berger and Udell, 1992; Borio, 1995). Some economists and policymakers have argued that an additional policy channel works through bank credit (Keeton, 1979; Stiglitz and Weiss, 1981). The credit channel of monetary policy mainly consists of agency problems due to asymmetric information and exorbitant contracts enforcement in the financial market. The credit channel operates via two main components, including the bank lending and balance sheet channel (Mishkin, 1995). For bank lending, a decrease in the money supply leads to a decrease in bank deposits, which further decreases the volume of money and bank loans, investment and, ultimately, aggregate demand. This channel allows monetary policy to operate without considering the interest rate, thus implying that a decrease in interest rates may not be sufficient to stimulate investment.

The balance sheet channel also works via the net worth of firms. A contractionary monetary policy can reduce the value of assets and raise business costs through high interest rates that reduce the net worth of firms. A decrease in the firm's net worth implies that lenders must accept less collateral for their loans, thus creating the problem of adverse selection and reducing lending for investment spending. Lower net worth also results in the problem of moral hazard as business owners have lower equity stakes in the firm and, thus less incentive to take part in risky projects, leading to less lending (Mishkin, 1995, cited in Le and Pfau, 2009). Following this, an expansionary monetary may take a longer time in terms of impact. In addition to credit market imperfections, the potency of monetary transmission mechanisms becomes weak (Gertler and Gilchrist, 1993).

\subsection{Empirical literature}

The monetary policy transmission channel occupies a critical place in policymaking, particularly for countries where it is impaired by structural factors. The literature suggests that the bank lending channel is weaker in developing economies than in advanced economies, but there is some debate on precisely the extent. On the relationship between monetary policy and bank lending, studies that found significant links are Bernanke and Blinder (1989, 1992), Bernanke and Getler (1989), Gianneti (2003), Bernake (2007), Kashyap and Stein (2000), Khwaja and Mian (2008), Saxegaard (2009), Jimenez et al. (2012, 2014, 2015), Van-Den-Heuvel (2012), Mishra and Montiel (2013), Altunbas et al. (2014), Bernardo et al. (2015), Berg and Portillo (2018), Berger et al. (2018), Berg et al. (2019), Abuka et al. (2015), among others. Bernanke (2007) and Berger et al. $(2018,2019)$ found that nearly half of the variation in market interest rates translates into changes in loan rates, indicating an economically significant pass-through. The evidence points further that better-capitalized banks transmit changes in monetary policy significantly less than lower-capitalized banks.

Amidu (2006) empirically investigates the nexus between monetary policy and bank lending and specifically, whether bank lending is inhibited by monetary policy in Ghana. Using money supply changes and central bank prime rate as a proxy for monetary policy and time-series data for the period 1998-2004, he finds that Ghanaian bank lending is significantly influenced by the country's economic activities and changes in the money supply. Further findings show that the central bank's prime rate and inflation rate have a 
negative and insignificant effect on bank lending, while firm-level specifics, such as bank size and liquidity have significant effects. Borio and Gambacorta (2017) investigate the effectiveness of monetary policy on bank lending in a low-interest rate environment, using evidence from a sample of 108 large international banks. The results show that reductions in short-term interest rates are less effective in stimulating bank lending growth when rates reach a very low level. The results are tenable after controlling for business and financial cycle conditions and different bank-specific characteristics such as liquidity, capitalization, funding costs, bank risk and income diversification. Further evidence points to the fact that low rates on the profitability of banks' traditional intermediation activity help explain the weak lending behavior of banks.

Mishra and Montiel (2013) show that the weak monetary policy transmission in developing countries is due to structural impediments. On the other hand, higher liquidity signifies financial health as banks characterized by higher liquidity have a greater capacity to protect their loan portfolio where there is monetary tightening by drawing down on the stock of liquid securities (Kashyap and Stein, 2000). Banks with more liquidity may also be seen as financially resilient and enjoy a lower cost of funds (Bernanke, 2007). The literature emphasizes the macroeconomic characteristics that weaken the bank lending channel in developing countries, such as smaller banking sectors, illiquid financial markets and uncompetitive banking architecture (Mishra and Montiel, 2013).

Saxegaard (2009) finds evidence that banks in Sub-Saharan Africa hold reserves in excess of the level consistent with a precautionary savings motive and suggests that excess liquidity in the banking system weakens the monetary transmission mechanism. Consistent with this, monetary policy transmission effectiveness between advanced economies and developing countries differs markedly, based on the degree of governance and institutional structures and the market incompleteness. For less developed countries, low degrees of intermediation ratios are the result of weak property rights and contractual frameworks that aggravate informational problems and financial frictions in lending (see Abuka et al., 2019). Other studies in this direction include Buli and Vlcek (2015), Barajas et al. (2018), Willems (2018) and Abuka et al. (2019).

An IMF (2015) study on the link between monetary policy and the real economy in developing countries is constrained by structural and institutional rigidities in the economic and financial space. Abuka et al. (2015), using evidence from a sample of developing countries, find that the transmission of monetary policy to the volume of credits and the real economy is impaired by weaknesses in the contracting environment due to shallow financial markets and concentrated banking systems. They utilize datasets of loan applications and loans granted to investigate the impact of monetary policy on bank lending and the real economy, focusing on a period of temporary variation (rise and fall) in the policy rate. The empirical findings show that an increase in interest rates reduces the supply of bank credit; an indication of a significant pass-through to retail lending rates. A different strong bank balance sheet channel, in terms of the lending behavior of banks with high capital and liquidity, is found compared to banks with low capital and liquidity. Further evidence reveals that monetary policy's effect on real economic activity depends on banking sector conditions.

In a similar dimension, Abuka et al. (2019) examine the link between monetary policy and bank lending in developing countries and the implications for loan applications, rates and real effects, drawing evidence from Uganda banks for the period 2010-2014. They utilized microdata on loan applications, volumes and rates, and unanticipated variation in monetary policy. Utilizing meneralized method of moments (GMM), the results show that monetary contraction reduces bank credit supply in terms of rejections of increasing loan applications and contraction, particularly for banks with high degrees of leverage and exposure to debts. Further findings show associated spillovers on inflation and economic activity.

Monetary policies and bank lending 
JED

24,3

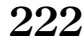

Gomez-Gonzalez and Grosz (2007) examine empirical evidence in support of bank lending channels for Argentina and Colombia using specific variables. For Columbia, the study reveals that monetary policy such as increments in interbank lending rate leads to a significant reduction in loan growth, but this impact differs across banks. Banks with lower capitalization and liquidity were more affected. For Argentina, the study finds no evidence to support the relationship between the interbank lending rate and the growth rate of loans. The two opposing results confirm the necessity for further empirical inquiry into the impact of monetary policy on bank lending.

Kishan and Opiela (2000) study the relationship between bank size, bank capital and bank lending channel in the USA from 1980 to 1995. The study segregated the selected banks according to asset size and capital leverage ratio. Their findings support the argument that bank asset size and bank capital affect the banks' ability to raise funds and maintain loan growth during contractionary policy. Small undercapitalized banks were found to be unable to generate alternative capital to finance loans during contractionary policy. This confirms the argument that small undercapitalized banks are most responsive to monetary policy.

Kishan and Opiela (2006) investigate separately the impact of expansionary and contractionary policy on the loan behavior of low- and high-capital banks, and between preBasel/FDICIA and post-Basel/FDICIA periods. Their findings that contractionary policy affects low capital banks. Interestingly, the study also finds that expansionary policy is not effective in stimulating the loan growth of low-capital banks. The study is consistent with lending channel predictions, but for post-Basel/FDICIA period, when the capital constraint is stringent relative to the pre-Basel/FDICIA period. Similarly, Kishan and Opiela (2012) identify a channel of monetary policy that operates through a risk pricing constraint in the jumbo $\mathrm{CD}$ market. The study finds unfavorable policy shocks increase the debt holder's perception of bank default, thereby increasing the risk premiums for some banks and reducing their propensity to grant loans to customers.

Gomez-Gonzalez et al. (2021) test the relationship between financial structures of banks on the bank lending channel of monetary policy transmission in Colombia using a sample of 51 commercial banks. The findings show that an increase in the monetary policy interest rate significantly reduces bank loan growth. However, the impact depends on the financial structure of the banks. Furthermore, the study identifies an asymmetric effect in which the bank lending channel is stronger in monetary contractions than during expansions. They argue this is possible because of the heterogeneous response of banks as a result of different levels of solvency. A related study by Heryán and Tzeremes (2017) confirms that the lending channels of banks are affected by changes in short-term interest rates and aggregate money supply. They however acknowledge that effects of monetary policy on bank lending vary among commercial banks in European Union (EU) countries.

From the review of the pertinent studies, there is a paucity of empirical studies on the monetary policy bank lending channel in the Sub-Saharan African region. This study, therefore, contributes to the existing literature on monetary policy and bank lending. In addition, apart from Abuka et al. (2019) who utilized the GMM estimation approach, the estimation procedure largely employed by previous studies did not account for country specificities. Given the inability of these approaches to address the issues of omitted variable bias, endogeneity of regressors, measurement error, unobserved country-specific and timeinvariant effects, this study adopts a model that accounts for the aforementioned issues.

\section{Methodology}

3.1 Model specification

To empirically capture the systematic link between monetary policy and bank lending in SubSaharan African countries, a stylized monetary policy bank lending model is presented: 


$$
L_{i, t}=f\left(M P_{i, t}, X_{i, t}\right)
$$

where $L_{i t}$ is the dependent variable, here total volume of loans granted by banks to GDP percent; MP is monetary policy proxied by changes in the monetary policy rate and money supply; $t, i$ s year fixed specific effect, and $X$ is a vector of additional macroeconomic variables in line with the literature, which influence bank lending (see Amidu, 2006; Borio and Gambarcota, 2017; Abuka et al., 2019). The variables include important bank-specific factors that influence the volume of loans granted to include; capital adequacy ratio, i.e. total regulatory capital (Tier $1+$ Tier 2) divided by risk-weighted assets and size of banks. The inclusion of these important bank-specific factors is hinged on the fact that banks that are well-capitalized in terms of vulnerability to risks and high liquidity can grant more loans than less capitalized and less liquid banks. In addition, inclusion is made for key macroeconomic variables that influence bank lending, controlling for GDP and inflation rate. This approach follows Kashyap and Stein (2000), Jiménez et al. (2012) and Abuka et al. (2019). The inclusion enables the effect of monetary policy transmission to vary with bank capital and size (Khwaja Mian, 2008) and economic conditions. Consequently, the expanded version of the model to capture the determinants of bank lending in Sub-Saharan African countries is:

$$
L_{i, t}=f\left(M S_{i, t}, M P_{i, t}, C A R_{i, t} B S_{i, t}, G R G D P_{i, t}, I N F_{i, t}\right)
$$

The empirical specification of the model is:

$$
L_{i, t}=\alpha_{0}+\alpha_{1} M S_{i, t}+\alpha_{2} M P_{i, t}+\alpha_{3} C A R_{i, t}+\alpha_{4} B S_{i, t}+\alpha_{5} G G D P_{i, t}+\alpha_{6} I N F_{i, t} \quad \varepsilon_{i, t}
$$

$\alpha_{1}-\alpha_{6}$ are parameters to be estimated, $t$ represents year-fixed specific effect and $\varepsilon$ is the unobserved error term.

A priori, we expect: $\alpha_{1}, \alpha_{3}, \alpha_{4}, \alpha_{5}>0 ; \alpha_{2}, \alpha_{6}<0$.

The estimation is done using the dynamic system-GMM estimator, which is asymptotically efficient, robust to heteroskedasticity and capable of addressing the problems of omission bias and reverse causality (simultaneity). While the static panel estimators (fixed or random effect assume considerable heterogeneity of the cross-sections), it does not efficiently address the problems of endogeneity, omission variable and unobserved effects in the determination of the dependent variable. Evidence has shown that examining variables across countries and time entails specifying a unique model to capture period and country-specific effects (economic idiosyncrasies) that are largely not observable and may likely result in potential endogeneity, making the system-GMM suitable in such situations. Furthermore, the system-GMM estimator provides highly precise and less biased estimates compared to the first-differenced-GMM estimator, as it combines the moment conditions for the first difference equations, using appropriately lagged variables as instruments.

\subsection{Definition of variables and sources of data}

The definitions of the variables in the model, unit of measurement, as well as sources of data, are provided in Table 1.

Data covering the period 2010-2019 for 80 banks across 20 Sub-Saharan African countries are used utilized for the study. The period and selection are dictated by data availability.

\section{Empirical results and analysis}

\subsection{Descriptive statistics}

Table 2 presents the descriptive statistics of the data on the variables used for the analysis. Total loans granted as the ratio of the total asset for the sampled Sub-Saharan African countries are $12.8 \%$, with a median value of $12.12 \%$, an indication of a differential rate of
Monetary policies and bank lending 


\section{JED 24,3}

224

Table 1.

Definition of variables and data sources

\begin{tabular}{ll}
\hline Variable & Description/measurement \\
\hline Lending & $\begin{array}{l}\text { Total volume of bank loans (credit) granted as } \\
\text { a ratio of total assets of banks }\end{array}$ \\
$\begin{array}{l}\text { Money supply } \\
\text { Monetary policy } \\
\text { rate } \\
\text { Growth rate of money supply to GDP percent }\end{array}$ & Anree months monetary policy rate \\
& Annal growth rate of nominal GDP percent
\end{tabular}

real GDP

Inflation rate

Growth rate of the consumer price index

Capital adequacy ratio

Bank size

Total regulatory capital (Tier $1+$ Tier 2)

Dummy variable that takes value 1 for banks with above-median total assets, 0 otherwise

Source(s): Authors' compilation, 2021
Source

Bank Reports

World Economic Outlook (IMF)

International Financial Statistics (IMF)

World Bank Development Indicators

(World Bank)

World Bank World Development Indicators (World Bank), World Trade Report

Financial Report of Banks, IMF

Financial Report of Banks, IMF

International Financial Statistics

\begin{tabular}{|c|c|c|c|c|c|c|}
\hline & & Mean & Median & Max & Min & Std. dev. \\
\hline & $L$ & 12.76 & 12.13 & 28.22 & 4.25 & 10.21 \\
\hline & $M S$ & 18.40 & 18.52 & 47.28 & 8.68 & 7.25 \\
\hline & $M P$ & 21.26 & 20.72 & 45.17 & 7.25 & 5.60 \\
\hline & $C A R$ & 23.00 & 22.85 & 32.22 & 10.72 & 7.20 \\
\hline & $G G D P$ & 3.40 & 3.06 & 8.25 & -1.56 & 7.15 \\
\hline Table 2. & $I N F$ & 14.2 & 13.64 & 27.43 & 3.45 & 15.43 \\
\hline Descriptive statistics & \multicolumn{6}{|c|}{ Source(s): Authors' computation, 2021} \\
\hline
\end{tabular}

lending among the countries. Money supply to GDP has a mean value of $18.4 \%$. The mean value of the capital adequacy ratio is $23 \%$. The maximum and minimum values are 32.2 and $10.7 \%$, respectively. The growth rate of real GDP and inflation rate have mean values of 3.4 and $14.2 \%$, respectively. Their standard deviation of 7.2 and 15.4 , respectively, show evidence of inflation and growth variability in Sub-Saharan African countries. Invariably, Sub-Saharan African countries are characterized by discernible macroeconomic instability.

\subsection{Regression results}

The results of the static panel estimation involving the fixed effect, using the Hausman selection criteria and the Arellano and Bover (1995) and Blundell and Bond (1998) systemGMM are reported in Table 3. Focus is on the system-GMM results that provide superior, consistent and efficient estimates to the fixed effects results. An examination of the results shows a positive but not significant lagged coefficient of lending, implying a non-significant link between previous bank lending position and the current lending position of banks. Thus, an asymmetric bank lending response to monetary policy exist in Sub-Saharan African countries such that past lending realizations do not significantly determine current lending of banks.

The coefficient of money supply is positively signed and significant at the $5 \%$ level, implying that increased money supply leads to greater bank lending. Thus, an expansionary money supply encourages greater bank deposits, with greater capacity for bank lending. By implication, money supply growth enhances bank lending, while a contraction reduces bank credit supply, as it leads to increased rejection of loan applications, tightening loan volume 
Dependent variable: Bank lending

Variable

$L(-1)$

$M S$

$M P$

CAR

$B S$

GGDP

INF

Adjusted $R^{2}$

$F$-statistic $=$

Breusch-Godfrey serial correlation LM test

Post-diagnostics

Instrument count

$J$-stat

$\operatorname{AR}(1)$

$\mathrm{AR}(2)$

Note(s): significance at the $10 \%$ level; $t$-ratios in parentheses
System-GMM

$0.010(0.063)$

$0.2213^{* *}(2.252)$

-0.121 (1.577)

$0.016^{* * *}(2.092)$

0.2031 (1.073)

$0.331^{* * *}(2.32)$

$-0.067(-1.232)$
Monetary

policies and bank lending

$25(1.282)$

$0.323^{* *}(2.22)$

$-0.021(0.121)$

0.83

43.10 [0.000]

1.83 [0.35]
9

$2.44(0.47)$

$-2.90(0.003)$

-0.60 (0.542)

Table 3.

Results of bank lending model

and rate, including the rationing of loans. The finding is consistent with Borio (1995) and Amidu (2006). A 1\% expansionary money supply leads to an increase in bank lending by $0.2 \%$.

The coefficient of the monetary policy rate is negatively signed but not significant. Since its t-value is greater than unity, the monetary policy rate has a weak impact on credit channels in developing countries arising from underdeveloped financial markets, institutional constraints and other structural inflexibilities that hamper monetary policy transmission effectiveness. The result buttresses the findings of Abuka et al. $(2015,2019)$ and Borio and Gambacorta (2017). A 1\% increase in policy rates decreases bank lending by $0.1 \%$.

The coefficients of capital adequacy ratio and bank size are appropriately positively signed in line with a priori expectation, but only the coefficient of capital adequacy ratio is statistically significant. Apparently, banks with higher capital adequacy ratios are more financially healthy, virile and stable to grant loans to customers than less capitalized banks since being well-capitalized implies less vulnerability to liquidity risks and systemic crisis. With a large pool of capital over risks, banks tend to have greater financial muscle and confidence to grant loans. The result supports the findings of Abuka et al. (2019).

Macroeconomic conditions - proxied by the growth of gross domestic product (GDP) and inflation rate are appropriately signed, but only the $t$-ratio of growth rate of GDP is significant. There are thus associated spillovers of inflation and economic activity on bank lending capacity, as rising economic activity tends to engender greater bank lending, while high inflation rate depresses financial intermediation. Ostensibly, a rise in economic activities implies greater profit for banks in line with the Pasinetti's profit growth model, thus, stimulating lending, while accelerating inflation creates instability in the economic environment, engendering uncertainty syndrome, leading to a decline in bank lending. The results are in harmony with Berger et al. (2018) and Abuka et al. (2019).

Regarding the post-diagnostic tests for robustness and validity of the results obtained, the Breusch-Godfrey serial correlation LM test shows the absence of serial correlation in the fixed static panel results, while the Hansen $J$-statistic of over-identifying restrictions verifies the validity of the instruments utilized in the estimation, thus confirming the consistency of the system-GMM estimator. The post-estimation evidence also leads to the rejection of the 
JED

24,3

null hypothesis of no serial correlation at order one in the first-difference errors, but a failure to reject same at order two (with $\mathrm{AR}(1)=-2.90(0.003) * * *$ and $\mathrm{AR}(2)=-0.60(0.54)$ ). There is, thus, no evidence to invalidate the model, considering that the estimates are robust in firstorder serial correlation, but not in the second-order serial correlation in the error terms. The model is, therefore, fit for structural and policy perspectives.

\section{Policy implications of findings}

Several important policy implications can be inferred from the empirical findings. First, there is evidence that an expansionary money supply, and thus liquidity, stimulate bank lending. By implication, bank lending is stimulated by greater monetary liquidity than a contractionary monetary policy. Monetary authorities in developing countries can, therefore, sufficiently rely on the money transmission mechanisms of changes in money supply to influence bank lending and real sector economic activity in developing countries.

Second, the findings suggest that a high monetary policy rate discourages bank lending in developing countries, albeit a weak impact, due perhaps to underdeveloped financial markets and institutional constraints that hamper monetary policy transmission effectiveness. Such increase in policy rate contracts credit due to crowding-out effect, complex and exorbitant collateral requirements, credit rationing, and hence, higher level of reluctance on the part of banks to lend. Effective policies to develop the financial system to remove financial inflexibilities and provide quality institutional settings are thus important to aid monetary policy transmission effectiveness.

Third, the empirical results point to the fact that high capital adequacy ratio is an important determinant of bank lending in Sub-Saharan Africa. Thus, well-capitalized banks have lower susceptibility to risks and are healthier and more stable to grant higher volumes of loans than banks with less capital base. Therefore, effective policy regulation and supervision of banks to meet the minimum capital adequacy ratio are important to guarantee the safety and viability of banks to carry out efficient financial intermediation.

Fourth, the empirical results suggest that increased economic activities are a pivotal stimulator for bank lending. As economic activities increase, the tendency and willingness of banks to lend are enhanced. Government and policymakers in developing countries should, therefore, put in place policies that will drive the growth of their economies to effectuate the credit intermediation role of banks. Finally, the results indicate that a high inflation rate discourages lending in developing countries as high and volatile inflation creates uncertainty and asymmetric lending behavior by banks.

\section{Conclusion}

The paper examined the nexus between monetary policy (with other control variables) and bank lending in the Sub-Saharan African region, using data for 80 banks across 20 sampled countries for the period 2010-2019. The empirical results show a significant impact of money supply on credit channels in Sub-Saharan African countries and a weak impact of monetary policy rate on lending activities of banks. The weak impact of monetary policy rate on lending may be attributable to the low level of financial development, bank concentration, institutional weakness and a host of other structural factors that tend to weaken the potency of monetary policy transmission in developing countries. Other factors that significantly influence bank loans are the capital adequacy ratio of banks and macroeconomic conditions, such as the growth rate of GDP (a proxy for economic activities).

One major limitation of our study is the paucity of data on all the 46 countries in SubSahara Africa. This lack of data is mainly due to the underdevelopment of the financial system of these countries coupled with weak public institutions and a culture of suppression of accountability. 
Based on the foregoing findings, developing countries, particularly, Sub-Saharan Africa can enhance the effectiveness of monetary policy transmission on bank lending through the effective use of the transmission mechanism of changes in money supply and changes in monetary policy rate (i.e. interest rate). Bank-specific factors that should be harnessed to encourage lending are capital adequacy and sound risk management efficiency, in addition to good macroeconomic variables in terms of improved economic growth rate and low and stable inflation rate.

Future empirical studies should expand the scope of this study by incorporating more countries into their samples. In addition, a combination of primary and secondary data may be employed to address the issue of missing data. This will make the findings of such students more generalizable and enrich the literature on bank lending channels.

\section{References}

Abuka, C., Alinda, R.K., Minoiu, C., Peydró, J.-L. and Presbitero, A.F. (2015), "Monetary policy and bank lending in developing countries: loan applications and real effects", IMF Working Paper WP/15/270, International Monetary Fund.

Abuka, C., Alinda, R.K., Minoiu, C., Peydró, J.L. and Presbitero, A.F. (2019), "Monetary policy and bank lending in developing countries: loan applications, rates, and real effects", Journal of Development Economics, Vol. 139, pp. 185-202, doi: 10.1016/j.deveco.2019.03.004.

Altunbas, Y., Gambacorta, L. and Marqués, D. (2014), "Does monetary policy affect bank risk?", International Journal of Central Banking, Vol. 10 No. 1, pp. 95-135.

Amidu, M. (2006), "The link between monetary policy and bank lending behaviour: the Ghanaian case", Banks and Banks System, Vol. 1 No. 4, pp. 38-48.

Arellano, M. and Bover, O. (1995), "Another look at the instrumental variable estimation of error components models", Journal of Econometrics, Vol. 68, pp. 29-51.

Balogun, O.C. (2009), "Financial structure, bank lending rate and the transmission mechanism of monetary policy", IMF Staff Papers, Vol. 41 No. 4, pp. 121-175.

Barajas, A., Chami, R., Ebeke, C. and Oeking, A. (2018), "What is different about monetary policy transmission in remittance-dependent countries", Journal of Development Economics, Vol. 134, pp. 272-288.

Beck, T., Levine, R. and Loayza, N. (2000), "Finance and the sources of growth", Journal of Finance and Economics, Vol. 58 No. 1, pp. 261-300.

Berg, A. and Portillo, R. (2018), Monetary Policy in Sub-Saharan Africa, Oxford University Press, Oxford.

Berg, A., Charry, L., Portillo, R. and Vicek, J. (2019), "The monetary transmission mechanism in the tropics. A case study approach", Journal of African Economics, Vol. 27 No. 6, pp. 112-128.

Berger, A.N. and Udell, G.F. (1992), "Some evidence on the empirical significance of credit rationing", Journal of Political Economy, Vol. 100 No. 5, pp. 1047-1077.

Berger, A.N., Guedhami, O., Kim, H.H. and Li, X. (2018), "Economic policy uncertainty and bank liquidity hoarding", available at: https://ssrn.com/abstract $=3030489$.

Bernado, M., Peydro, J. and Ruiz, C. (2015), “The international bank lending channel of monetary policy rates and QE: credit supply, reach-for-yield, and real effects", FRB International Finance Discussion Paper No. 1137, FRB International Finance.

Bernanke, B. (2007), The Financial Accelerator and the Credit Channel, Speech Delivered at the Board of Governors of the US Federal System, Washington, DC, June 15.

Bernanke, B. and Blinder, M. (1989), "Money, credit, and aggregate demand", American Economic Review, Vol. 82, pp. 901-921.

Monetary policies and bank lending

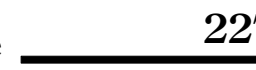


Bernanke, B.S. and Blinder, A.S. (1992), "The Federal funds rate and the channels of monetary transmission", American Economic Review, Vol. 82 No. 4, pp. 901-921.

Bernanke, B. and Gertler, M. (1989), "Inside the black box: the credit channel of monetary policy transmission", American Economic Review, Vol. 79 No. 1, pp. 14-31.

Blundell, R. and Bond, S.R. (1998), "Initial conditions and moment restrictions in dynamic panel data models", Journal of Econometrics, Vol. 87, pp. 115-143.

Borio, C. (1995), "The structure of credit to the non-government sector and the transmission mechanism of monetary policy: a cross-country comparison”, Bank for International Settlement Working Paper No. 24, BIS, available at: https://www.bis.org/publ/work24.htm.

Borio, C. and Gambacorta, L. (2017), "Monetary policy and bank lending in a low-interest-rate environment: diminishing effectiveness?”, BIS Working Paper No. 612, BIS.

Buli, A. and Vicek, J. (2015), "Monetary transmission: are emerging markets and low-income countries different?", IMF Working Paper 15/239, IMF.

Friedman, M. (1968), “The role of monetary policy”, American Economic Review, Vol. 58 No. 1, pp. 1-17.

Friedman, M. and Schwartz, A. (1963), "Money and business cycles", Review of Economics and Statistics, Vol. 45 No. 1, pp. 32-64.

Gertler, M. and Gilchrist, S. (1993), "The role of credit market imperfections in the monetary transmission mechanism: arguments and evidence", Scandinavian Journal of Economics, Vol. 95 No. 1, pp. 43-64.

Gianneti, M. (2003), "Bank-firm relationships and contagious banking crises”, Journal of Money, Credit and Banking, Vol. 35, pp. 239-261.

Gomez-Gonzalez, J.E. and Grosz, F. (2007), "Evidence of a bank lending channel for Argentina and Colombia”, Cuadernos de Economía, Vol. 44, pp. 109-126.

Gomez-Gonzalez, J.E., Kutan, A., Ojeda-Joya, J.N. and Ortiz, C. (2021), "Does the financial structure of banks influence the bank lending channel of monetary policy? Evidence from Colombia", International Journal of Emerging Markets, Vol. 16 No. 4, pp. 765-785.

Heryán, T. and Tzeremes, P.G. (2017), "The bank lending channel of monetary policy in EU countries during the global financial crisis", Economic Modelling, Vol. 6, pp. 10-22.

IMF (2015), "Evolving monetary policy frameworks in low-income and other developing countries", IMF Staff Paper, available at: https://www.imf.org/external/np/pp/eng/2015/102315.pdf.

Iyoha, M.A. (2004), Macroeconomics Theory and Policy, Mindex and Benin City.

Jiménez, G., Ongena, S., Peydró, J. and Saurina, J. (2012), "Credit supply and monetary policy: identifying the bank-balance sheet-channel with loan applications", American Economic Review, Vol. 102 No. 5, pp. 2121-2165.

Jiménez, G., Ongena, S., Peydró, J. and Saurina, J. (2014), "Hazardous times for monetary policy: what do twenty-three million bank loans say about the effects of monetary policy on credit risktaking?”, Econometrica, Vol. 82 No. 2, pp. 463-505.

Jiménez, G., Mian, A.R. and Peydró, J. (2015), “The real effects of the bank lending channel”, CREI Working Paper, CREI.

Kashyap, A.K. and Stein, J.C. (2000), "What do a million observations on banks say about the transmission of monetary policy?", American Economic Review, Vol. 90 No. 3, pp. 407-428.

Keeton, W. (1979), Equilibrium Credit Rationing, Garland Press, New York.

Khwaja, A.I. and Mian, A. (2008), "Tracing the impact of bank liquidity shocks: evidence from an emerging market”, American Economic Review, Vol. 98 No. 4, pp. 1413-1442.

Kishan, R.P. and Opiela, T. (2000), "Bank Size, Bank Capital, and the bank lending channel”, Journal of Money, Credit, and Banking, Vol. 32 No. 1, pp. 121-141.

Kishan, R.P. and Opiela, T. (2006), "Bank capital and loan asymmetry in the transmission of monetary policy", Journal of Banking and Finance, Vol. 30 No. 1, pp. 259-285. 
Kishan, R.P. and Opiela, T. (2012), "Monetary policy, bank lending, and the risk-pricing channel", Journal of Money, Credit, and Banking, Vol. 44 No. 4, pp. 573-602.

Le, H.V. and Pfau, W.D. (2009), "VAR analysis of the monetary transmission mechanism in Vietnam", Applied Econometrics and International Development, Vol. 9 No. 1, pp. 165-179.

Levine, R., Loayza, N. and Beck, T. (2000), "Financial intermediation and growth: causality and causes", Journal of Monetary Economics, Vol. 46 No. 1, pp. 31-77.

Mishkin, F. (1995), "Symposium on the monetary transmission mechanism", The Journal of Economic Perspectives, Vol. 9 No. 4, pp. 3-10.

Mishra, P. and Montiel, P. (2013), "How effective is monetary transmission in developing countries? A survey of the empirical evidence”, Economic Systems, Vol. 37 No. 2, pp. 187-216.

Mishra, P., Montiel, P. and Spilmbergo, A. (2012), "Monetary policy and bank lending rates in lowincome countries: effectiveness and policy implications", IMF Economic Review, Vol. 60 No. 2, pp. 270-302.

Modigliani, F. (1963), "The monetary mechanism and its interaction with real phenomena", Review of Economics and Statistics, Vol. 95, pp. 79-107.

Onyiewu, C. (2011), Monetary Policy and Economic Growth of Nigeria, Department of Economics, University of Lagos.

Owoye, O. and Onafowora, A.O. (2007), "M2 targeting, money demand and real GDP growth in Nigeria: do rules apply?", Journal of Business and Public Affairs, Vol. 1 No. 2, pp. 25-34.

Ozekhome, H.O. (2018), "Does money supply growth cause inflation in the West African Monetary Zone?", The West African Journal of Monetary and Economic Integration, Vol. 17 No. 2, pp. $57-90$.

Saxegaard, M. (2009), "Excess liquidity and effectiveness of monetary policy: evidence from SubSaharan Africa”, IMF Working Paper 06/115, International Monetary Fund.

Stiglitz, J.E. and Weiss, A. (1981), "Credit rationing in markets with imperfect information", American Economic Review, Vol. 71 No. 3, pp. 393-410.

Van de-Heuven, S. (2012), "Banking conditions and the effects of monetary policy: evidence from the United States”, B.E. Journal of Macroeconomics, Vol. 12 No. 2, pp. 67-90.

Willems, T. (2018), "What do monetary contractions do? Evidence from an algorithmic identification procedure”, IMF Working Paper 18/211, International Monetary Fund.

\section{Further reading}

Borio, C., Gambacorta, L. and Hofmann, M. (2017), "The effects of monetary policy on bank profitability”, BIS Working Papers No 514, BIS.

\section{Corresponding author}

Kennedy Prince Modugu can be contacted at: princekenny2010@gmail.com

Monetary policies and bank lending 